\title{
Effect of Contact Time of Gaseous Phase in Multi-Stage Contact Columns in Intermediate Ozonation Process on Reduction of Bromate Concentration
}

Abstract: This article describes research on the application of ozone technology for the purification of surface water in the presence of bromides. The pilot system used multistage contact columns for water-ozonation processes with stabilized contact time. The research has shown that the basis for limiting the formation of bromates is the optimum amount of residual ozone after the ozonation process and the constant time of ozone contact with the water. This solution allows us to reduce the formation of harmful compounds and apply ozone technology with water containing carcinogenic precursors.

Keywords: ozone, multi-stage contact columns, residual ozone, fixed contact time, bromates

Received: 11 October 2017; accepted: 24 June 2019

\footnotetext{
1 WOFIL OZONE TECHNOLOGY, Krynica-Zdrój, Poland, email: wofil@wofil.pl ORCID ID: https://orcid.org/0000-0001-7257-9558
} 


\section{Introduction}

Due to its properties, ozone is one of the most effective disinfectants - more powerful than chlorine and its compounds. Ozone reacts easily with many water pollutants. It is unstable, which is reflected by its tendency to decompose when dissolved in water, for example [1, 2]. This can be seen in an alkaline environment to a greater extent. The chemistry of ozone in an aquatic environment is complex and has been described in numerous monographs [3: 1, 2].

Most of the works on ground- and surface-water ozonation published so far have considered the disinfecting properties of ozone to a great extent [3: 46-49, 4], excluding its oxidizing capacity and ability to agglomerate organic and non-organic compounds. It is worth noting that, in all water treatment techniques and processes, additional procedures such as aeration, coagulation, and filtration are applied, helping to ensure the appropriate water parameters [5].

If we consider the use of ozonation as one of the components of a modern water treatment system, we will see that:

- aeration can be carried out with the use of desorbed ozone from the contact tanks, which quickly and reactively conducts pre-aeration and oxidation reactions;

- coagulation processes occur more quickly and require smaller doses of reagents;

- the filters achieve maximum efficiency faster, and the agglomeration of particles increases the rate of filtration [3: 109-112,6].

Implementing the process of ozonation to support the above individual processes makes the investment and exploitation costs of complex water treatment systems considerably lower. For instance, the pre-aeration of water conducted with the use of a standard aerator requires 10-20 minutes of contact time, while the same process carried out with the use of ionized ozone required 2-5 minutes. This affects the size of the equipment $[7,8]$.

The aim of the study described in this article was to prove the relevancy of the use of vertical multi-stage contact columns in the process of indirect ozonation. This solution allows us to significantly reduce the risk of the formation of harmful compounds such as bromates in the process of water treatment. In this study, we have evaluated and analyzed the influence of the time of contact of the gaseous phase with the water after the first stage of filtration on the reduction of bromate concentration in the process of intermediate ozonation in multi-stage vertical contact columns.

\section{Research Methodology and Equipment}

The study was conducted with the use of a pilot system basing on a two-stage ozonation process. The pre-ozonation process was conducted with the use of an 
aerator/desorber, which uses the ozone desorbed from contact columns mixed with clean filtered air. Intermediate ozonation was carried out in the contact columns at two stages (overflows), adapted to operate with a variable flow. In the process, raw water was used with no added coagulants and other chemical compounds.

The surface water subjected to the ozonation process contained bromide ions - precursors to the formation of bromates. Therefore, the research focused on determining the operating parameters of the installation in order to limit the formation of these compounds (the standard is $10 \mu \mathrm{g} / \mathrm{dm}^{3}$ ).

The ozone system used in the study is equipment for ozone generation and feeding it into the water with an ozone injection system. The ozone system consisted of an oxygen generator, an ozone-generating unit, two-stage contact columns, a dissolved ozone monitor (residual ozone measurement in water), and an ozone injection/mixing system [7]. A diagram illustrating the pilot system used in the study is shown in Figure 1.

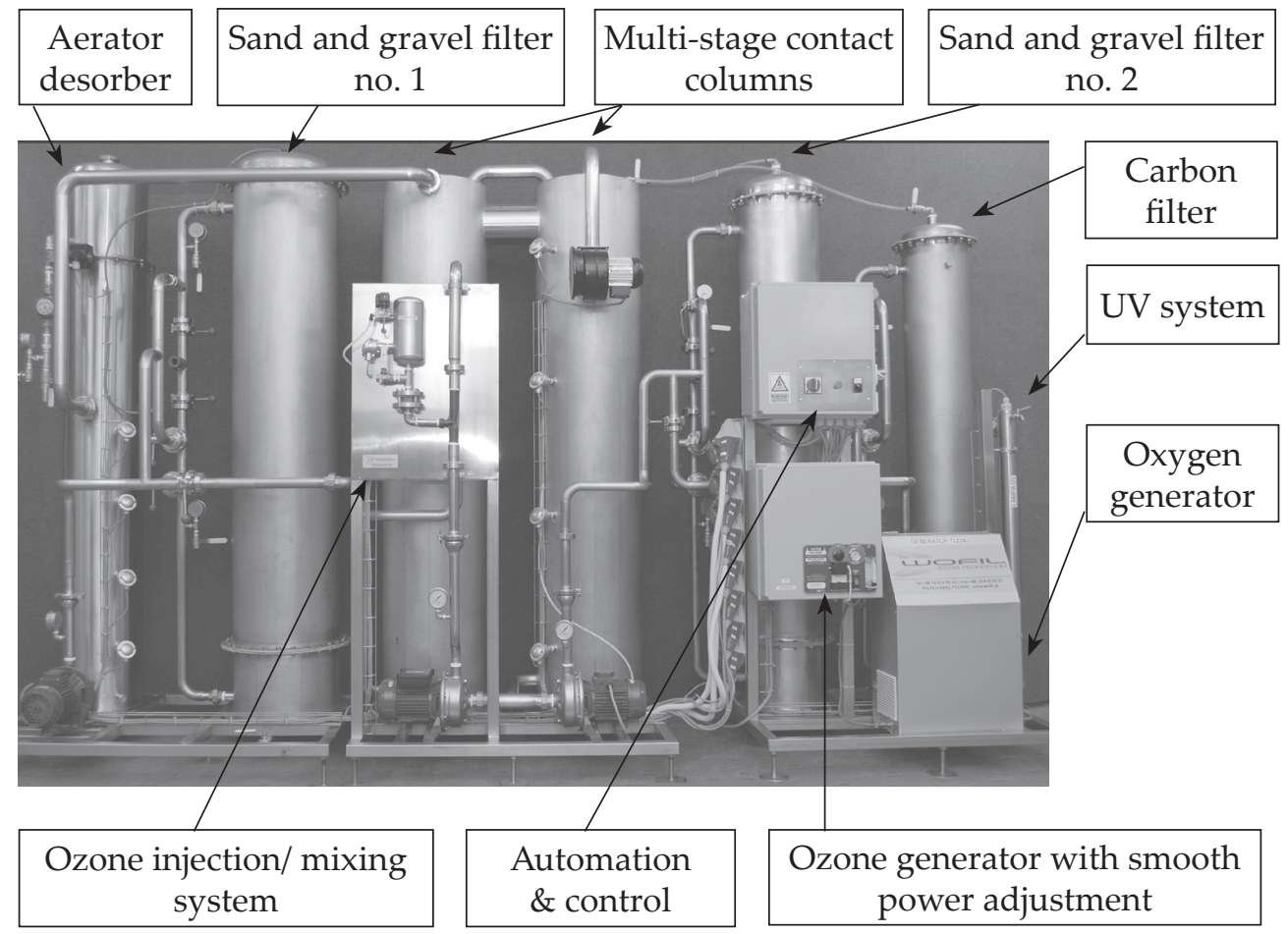

Fig. 1. Layout of pilot system used in study 
In the study, vertical multi-stage contact columns were used with the following specifications:

- columns no. 1 (first overflow): oxidating and upflowing column plus degassing column,

- columns no. 2 (second overflow): oxidating and upflowing column and degassing column.

The columns are adapted to work with variable flow rates within 0.5 to $2.0 \mathrm{~m}^{3} / \mathrm{h}$. For a better illustration of the work of the multi-stage columns with variable flows, the research was conducted at three contact times of water with ozone in accordance with the following flow rates:

- $1 \mathrm{~m}^{3} / \mathrm{h}$ - contact time of approx. 10 minutes (first stage),

- $1 \mathrm{~m}^{3} / \mathrm{h}$ - contact time of approx. 20 minutes (second stage),

- $0.5 \mathrm{~m}^{3} / \mathrm{h}$ - contact time of approx. 50 minutes (second stage).

\subsection{System Description}

Raw water from the main pipeline enters the equalization tank. It is then pumped to the aerator desorber. The raw water enters the aerator desorber, where potential particles of dissolved gases are removed. Simultaneously, the water is aerated with air enriched with the excess ozone desorbed from the contact columns (ionized air) for the purpose of pre-oxidating the easily-oxidized compounds at this stage of the technology. Pre-oxidation in the aerator supports the filtration processes at the first stage of filtration. Additionally, a water/gas trap was installed for safety purposes, enabling the drainage of excess water with the separation of ozone when the level in the aerator is too high. This device is indispensable in systems where ozone is used for water oxidation and disinfection. The aerator-desorbers equipped with complete piping, fittings, and a set of sensors.

The pilot system designed for the ozonation of surface water with bromides is shown in Figure 2.

After pre-oxidation with ionized air, raw water is pumped to undergo the first stage of filtration - gravel and sand filtration. Then, the treated water enters the twostage contact columns (which are elements of the ozone system).

The filtered water from the first stage of filtration is pumped to two-stage contact columns: column no. 1 and column no. 2. An ozone injection system with a circulating pump is installed before the contact columns. Ozone is generated from the oxygen supplied by the oxygen generator. In the contact columns, the processes of oxidation and partial disinfection take place. The excess gas (ozone) remains in the columns, which desorbs from the ozonated water. It is then mixed with air in the degassing column and - already in the form of ionized air - is supplied to the aerator desorber.

The ozone generator (max efficiency: $20 \mathrm{~g} \mathrm{O}_{3} / \mathrm{h}$ ) with an air-cooled electrode is used for the generation of ozone for the process of the oxidation of organic and 
inorganic impurities in the water. It features a smooth control of power (efficiency 1-100\%), enabling the remote adjustment of the unit with a potentiometer.

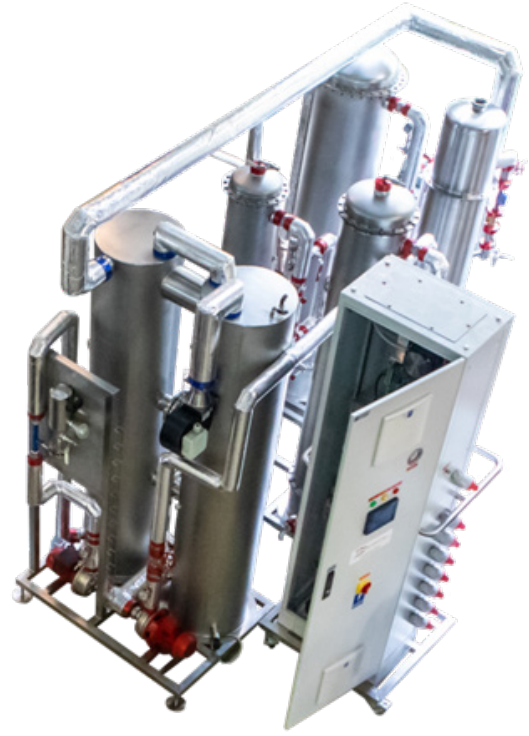

Fig. 2. Pilot system for ozonation of surface water

Source: [9]

The ozone is pressure-supplied to the separator, which is fitted with devices preventing access of the water to:

- an injector,

- an ozone separator,

- a pneumatic stop valve.

After contact with column no. 2, the water is pumped to the carbon filter (II ${ }^{\circ}$ filtration). The filtration process is automatic, whereas the backwash processes are manual. After the $\mathrm{II}^{\circ}$ filtration, the water flows through a UV lamp for the continuous disinfection of the treated water. There, a low pressure lamp of maximum efficiency is used: $1 \mathrm{~m}^{3} / \mathrm{h}$ (min. dose $-400 \mathrm{~J} / \mathrm{m}^{2}$ for transmission $\mathrm{T}=98 \%$ ).

During the research works, the sand and gravel as well as the carbon filters were backwashed to remove solid impurities as well as those oxidized and filtered through the bed. Rinsing was carried out once a day. Samples for the tests were taken at least two hours after the bed was washed out and the filter stabilized.

In the research, a device for measuring the residual ozone level in the water after the ozonation process was used (i.e., ozone remained in the water after the reaction) in order to determine the constant dose of ozone to be injected into the water. Residual ozone was tested every three hours in the water after the degassing column. 


\section{Study Results and Result Analysis}

The study focused on determining the residual ozone after the oxidation process, the concentration of the ozone dozed to the water, the amount of water flowing through the multi-stage columns within a specified amount of time, and the concentration of bromate in the water after each technological process. Due to the fact that ozone was used only for water oxidation, the focus was not on water disinfection and bacteriological tests during the test period. For disinfection after the pilot system, sodium hypochlorite was used - this has not been presented in the study's results. The turbidity, color, and manganese were determined during the tests for comparison purposes.

The raw water used in the study was taken from the pipeline of the main water treatment plant, which draws water from the surface water intake. The first water parameters are shown in Table 1. During the tests, the parameters varied due to the matrix of the surface water.

Table 1. Raw water used in study

\begin{tabular}{|c|c|c|c|}
\hline Type of test & Unit & Test result & Acceptable value \\
\hline Coliform bacteria & {$\left[\mathrm{cfu} / 100 \mathrm{~cm}^{3}\right]$} & 547 & 0 \\
\hline Escherichia coli & {$\left[\mathrm{cfu} / 100 \mathrm{~cm}^{3}\right]$} & 17 & 0 \\
\hline Color & {$\left[\mathrm{mg} / \mathrm{dm}^{3} \mathrm{Pt}\right]$} & 26 & $\begin{array}{l}\text { acceptable to consumers } \\
\text { and no abnormal change }\end{array}$ \\
\hline Turbidity & [NTU] & 6.36 & 1.00 \\
\hline Odor & {$[-]$} & acceptable & acceptable \\
\hline $\mathrm{pH}$ & {$[-]$} & 7.9 & $6.5-9.5$ \\
\hline Bromates & {$\left[\mu \mathrm{g} / \mathrm{dm}^{3}\right]$} & 0.7 & 10.0 \\
\hline Manganese & {$\left[\mu \mathrm{g} / \mathrm{dm}^{3}\right]$} & 17.7 & 50.0 \\
\hline $\begin{array}{l}\text { Permanganate index } \\
\text { (oxidizability) }\end{array}$ & {$\left[\mathrm{mg} / \mathrm{dm}^{3}\right]$} & 3.1 & 5.0 \\
\hline
\end{tabular}

* In accordance with Regulation of Minister of Health of December 7, 2017, on quality of water intended for human consumption (Journal of Laws 2017, Item 2294),

** Desired value in water at consumer's tap - up to $15 \mathrm{mg} / \mathrm{dm}^{3} \mathrm{Pt}$.

Source: [9]

Table 2 presents the results of the performed tests, and the subsequent testing days were marked as subsequent experiments (tests). Sampling point sampling is marked in bold in the table in accordance with the technological diagram used for the tests. 
Table 2 Quality parameters of water obtained during studies with use of pilot ozone system

\begin{tabular}{|c|c|c|c|c|c|c|c|}
\hline $\begin{array}{c}\text { Sampling } \\
\text { point }\end{array}$ & $\begin{array}{r}\text { Flow } \\
{\left[\mathrm{m}^{3}\right]}\end{array}$ & $\begin{array}{c}\text { Ozone } \\
\text { dosage } \\
{\left[\mathrm{g} / \mathrm{m}^{3}\right]}\end{array}$ & $\begin{array}{l}\text { Residual } \\
\text { ozone } \\
{\left[\mathrm{mg} / \mathrm{dm}^{3}\right]}\end{array}$ & $\begin{array}{l}\text { Turbidity } \\
\text { [NTU] }\end{array}$ & $\begin{array}{c}\text { Color } \\
{\left[\mathrm{mg} / \mathrm{dm}^{3} \mathrm{Pt}\right]}\end{array}$ & $\begin{array}{c}\text { Manganese } \\
{\left[\mu \mathrm{g} / \mathrm{dm}^{3}\right]}\end{array}$ & $\begin{array}{l}\text { Bromates } \\
{\left[\mu \mathrm{g} / \mathrm{dm}^{3}\right]}\end{array}$ \\
\hline \multicolumn{8}{|c|}{ Raw water } \\
\hline Test 1 & 1.0 & - & - & 2.89 & 11 & 38.6 & 0.1 \\
\hline Test 2 & 1.0 & - & - & 2.50 & 10 & 40.5 & 0.1 \\
\hline Test 3 & 1.0 & - & - & 1.87 & 10 & 36.8 & 0.3 \\
\hline Test 4 & 1.0 & - & - & 1.51 & 10 & 36.8 & 0.7 \\
\hline Test 5 & 1.0 & - & - & 6.37 & 7 & 270.0 & 0.1 \\
\hline Test 6 & 0.5 & - & - & 4.86 & $-{ }^{*}$ & $-^{*}$ & 0.1 \\
\hline Test 7 & 1.0 & - & - & 2.67 & $-{ }^{*}$ & $-{ }^{*}$ & 0.3 \\
\hline \multicolumn{8}{|c|}{ After aerator (ionized air) } \\
\hline Test 1 & 1.0 & - & - & 1.54 & 10 & 19.8 & 0.0 \\
\hline Test 2 & 1.0 & - & - & 1.66 & 10 & 22.9 & 0.1 \\
\hline Test 3 & 1.0 & - & - & 1.63 & 9 & 26.5 & 0.5 \\
\hline Test 4 & 1.0 & - & - & 1.51 & 9 & 26.5 & 0.3 \\
\hline Test 5 & 1.0 & - & - & 4.82 & 5 & 250.0 & 0.1 \\
\hline Test 6 & 0.5 & - & - & 5.05 & $--^{*}$ & $-^{*}$ & 0.1 \\
\hline Test 7 & 1.0 & - & - & 0.14 & $-{ }^{*}$ & $-^{*}$ & 0.7 \\
\hline \multicolumn{8}{|c|}{ After sand and gravel filter } \\
\hline Test 1 & 1.0 & - & - & 1.04 & 10 & 8.3 & 0.0 \\
\hline Test 2 & 1.0 & - & - & 1.08 & 9 & 5.4 & 0.2 \\
\hline Test 3 & 1.0 & - & - & 0.98 & 8 & 0.4 & 0.2 \\
\hline Test 4 & 1.0 & - & - & 0.87 & 8 & 0.4 & 0.3 \\
\hline Test 5 & 1.0 & - & - & 1.52 & 1 & 18.7 & 0.1 \\
\hline Test 6 & 0.5 & - & - & 1.08 & $-{ }^{*}$ & $-{ }^{*}$ & 0.2 \\
\hline Test 7 & 1.0 & - & - & 0.12 & $-^{*}$ & $-^{*}$ & 0.2 \\
\hline \multicolumn{8}{|c|}{ After intermediate ozonation } \\
\hline Test 1 & 1.0 & 2.0 & 0.05 & 0.92 & 3 & 8.2 & 0.4 \\
\hline Test 2 & 1.0 & 2.5 & 0.10 & 0.98 & 3 & 5.1 & 3.4 \\
\hline Test 3 & 1.0 & 3.0 & 0.15 & 0.86 & 3 & 0.4 & 3.6 \\
\hline Test 4 & 1.0 & 3.2 & 0.20 & 0.62 & 3 & 0.4 & 3.8 \\
\hline Test 5 & 1.0 & 3.2 & 0.05 & 1.17 & 5 & 16.7 & 1.7 \\
\hline Test 6 & 0.5 & 3.9 & 0.25 & 0.89 & $-{ }^{*}$ & $-^{*}$ & 24.0 \\
\hline Test 7 & 1.0 & 2.5 & 0.15 & 0.11 & $-^{*}$ & $-^{*}$ & 4.2 \\
\hline
\end{tabular}


Table 2. cont.

\begin{tabular}{|l|c|c|c|c|c|c|c||}
\hline $\begin{array}{c}\text { Sampling } \\
\text { point }\end{array}$ & $\begin{array}{c}\text { Flow } \\
{\left[\mathrm{m}^{3}\right]}\end{array}$ & $\begin{array}{c}\text { Ozone } \\
\text { dosage } \\
{\left[\mathrm{g} / \mathrm{m}^{3}\right]}\end{array}$ & $\begin{array}{c}\text { Residual } \\
\text { ozone } \\
{\left[\mathrm{mg} / \mathrm{dm}^{3}\right]}\end{array}$ & $\begin{array}{c}\text { Turbidity } \\
{[\mathrm{NTU}]}\end{array}$ & $\begin{array}{c}\text { Color } \\
{\left[\mathrm{mg} / \mathrm{dm}^{3} \mathrm{Pt}\right]}\end{array}$ & $\begin{array}{c}\text { Manganese } \\
{\left[\mu \mathrm{g} / \mathrm{dm}^{3}\right]}\end{array}$ & $\begin{array}{c}\text { Bromates } \\
{\left[\mu \mathrm{g} / \mathrm{dm}^{3}\right]}\end{array}$ \\
\hline \hline \multicolumn{7}{|c|}{ After carbon filter } \\
\hline Test 1 & 1.0 & - & - & 0.67 & 3 & 10.2 & 0.3 \\
\hline Test 2 & 1.0 & - & - & 0.47 & 2 & 1.4 & 3.3 \\
\hline Test 3 & 1.0 & - & - & 0.71 & 3 & 1.2 & 4.3 \\
\hline Test 4 & 1.0 & - & - & 0.59 & 3 & 1.2 & 9.1 \\
\hline Test 5 & 1.0 & - & - & 1.04 & 1 & 6.5 & 1.8 \\
\hline Test 6 & 0.5 & - & - & 0.89 & $-{ }^{*}$ & $-{ }^{*}$ & 21.4 \\
\hline Test 7 & 1.0 & - & - & 0.07 & $--^{*}$ & $--^{*}$ & 3.6 \\
\hline
\end{tabular}

* Due to damage to apparatus, color and manganese were not measured.

Source: [9]

The results of the studies show that, during the first four days of the study, the maximum raw water turbidity amounted to 2.89 NTU, the maximum ozone dosage amounted to $3.2 \mathrm{~g} / \mathrm{m}^{3}$, the minimum turbidity after carbon filtering amounted to $0.47 \mathrm{NTU}$, and the maximum stabilized residual ozone amounted to $0.2 \mathrm{mg} / \mathrm{dm}^{3}$. With such ozone system settings, the water quality was within the standards, and the concentration of bromates did not exceed $9.1 \mu \mathrm{g}$. It may be observed that, as the residual ozone increased, the bromate concentration increased as well after intermediate ozonation.

It must be stated that the concentration of bromates at a reaction time of up to 12 minutes and maximum residual ozone of $0.2 \mathrm{mg} / \mathrm{dm}^{3}$ for a different water matrix may vary. Moreover, other parameters not tested in the research may also affect the process. Therefore, the pilot tests are so crucial for the ozone technology in order to choose the appropriate dosages and reaction times. It is important to add that the reaction time should be constant, which was hardly achievable with the reactors applied thus far.

On the fifth consecutive day, the residual ozone concentration after contact with column no. 2 decreased due to the worse quality of the raw water flowing into the pilot system. This effect was observed at a constant dosing of ozone to water. This affected the bromate formation - its concentration lowered. It turns out that the increased concentration of all easily and hardly oxidized compounds has a considerable influence on the decomposition and use of ozone [7]. It also deeply affects bromate formation despite the constant water flow through the installations.

On the sixth day, the time of water retention in the contact columns was doubled (by reducing the flow rate from 1 to $0.5 \mathrm{~m}^{3}$ ). The contact time was approximate- 
ly 50 minutes. The concentration of the residual ozone in the water after contact with column no. 2 increased as well. With such operating settings of the pilot system, the bromate concentration exceeded the standard range by $100 \%$, amounting to about $20 \mu \mathrm{g}$. Such an increase in bromate concentration after the ozonation process was caused by the better raw water quality and reduced ozone demand. Longer ozone contact time in a contact column with a small increase in the dosed ozone is another example that proves that the water quality has a considerable influence on the bromate formation in the water after the ozonation process. Ozone does not decompose rapidly despite the long reaction time [2].

On the seventh day, the water quality was again better. This was related to the improvement of the water parameters of the river. The dosing of ozone to water was reduced. Residual ozone concentration after contact with column no. 2 was set at $0.15 \mathrm{mg} / \mathrm{dm}^{3}$, with a flow rate of $1 \mathrm{~m}^{3}$.

- At a concentration of residual ozone of between 0.1 and $0.2 \mathrm{mg} \mathrm{O}_{3} / 1$ and a contact time of over 25 minutes, the concentration of bromates amounted to $20 \mu \mathrm{g} / \mathrm{dm}^{3}$.

- At a concentration of residual ozone within the limits given above and a constant contact time of less than $\mathbf{2 5}$ minutes, the concentration of bromates amounted to no more than $9 \mu \mathrm{g} / \mathrm{dm}^{3}$.

The diagram below (Fig. 3) illustrates the effect of the residual ozone concentration on bromate concentration.

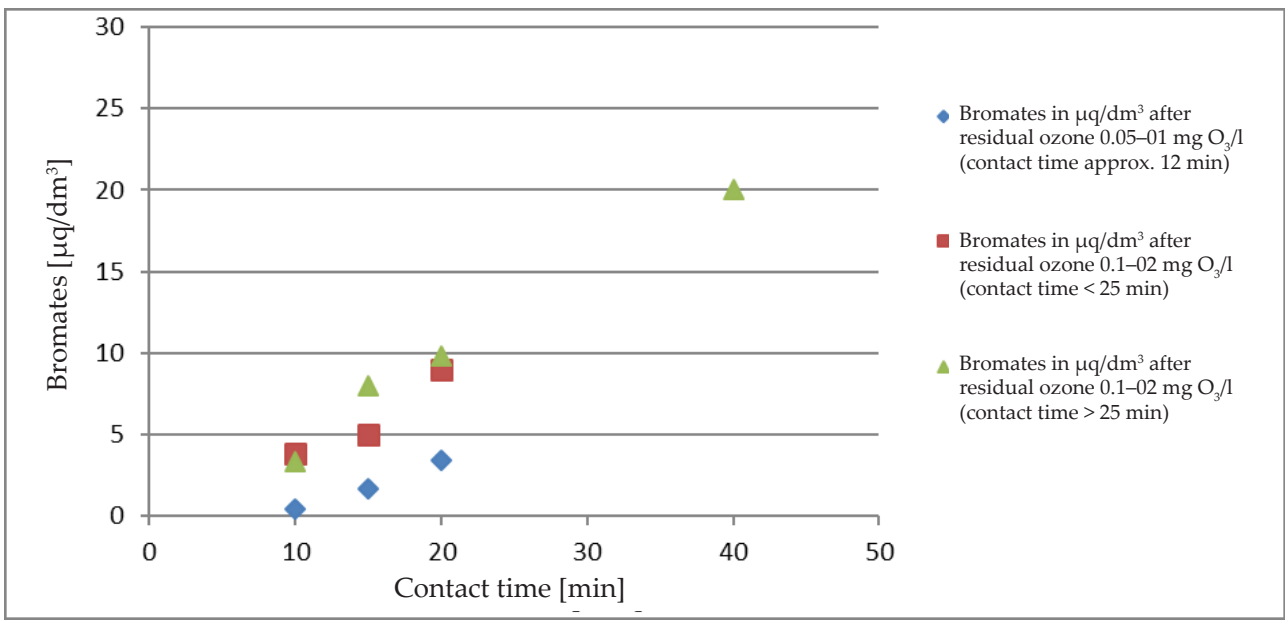

Fig. 3. Effect of residual ozone concentration on bromate concentration

Source: [9]

The study results show that $0.15 \mathrm{mg} / \mathrm{dm}^{3}$ is the most appropriate concentration of residual ozone for such a water matrix (water quality) following the ozonation 
process due to the small amount of bromates formed following this process. The bromate concentration at a constant flow rate of water passing through the contact columns was $3.6 \mu \mathrm{g} / \mathrm{dm}^{3}$.

\section{Conclusions}

The study conducted on the pilot system has shown that the basic (crucial) parameters that could and should be used for the control of the water purification process in the ozone technology include the residual ozone concentration in the water after the contact columns and the relatively constant contact time of the ozone with the water. The constant contact time is especially important in oversized systems. Moreover, it is the residual ozone concentration that enables optimal control of the process, not the amount of ozone dosed into the water (mainly with variable flow rates and water quality). While the increase in the residual ozone concentration in water causes a slight increase in the concentration of bromates, the longer time of ozone reaction with water that contains bromides in a contact tank results in a substantial increase in the concentration of bromates in the water after the ozonation process. This is shown in the graphics for contact times above 25 min in Figure 3.

Extending the contact time in the contact tanks is characteristic for installations operating with high production variability within 24 hours (production at night). For most ozone systems with variable water matrix parameters, it is sufficient to sustain a constant flow through the contact tank and to automatically maintain the residual ozone concentration after the process of ozonation (at 0.1 to $0.15 \mathrm{mg} \mathrm{O}_{3} / \mathrm{l}$ ).

The conducted research proved the effectiveness of water ozonation processes in multi-stage contact columns in the presence of precursors of carcinogenic compounds such as bromides. In treated water after multi-stage contact columns, reduced concentrations of ozonation by-products in the form of carcinogenic compounds (bromates, formaldehydes) were recorded; therefore, the solutions of the new technology prevent their formation.

\section{References}

[1] Hua G., Reckhow D.A.: Effect of pre-ozonation on the formation and speciation of DBPs. Water Research, vol. 47, 2013, pp. 4322-4330.

[2] Perkowski J., Zarzycki R. (red.): Występowanie i właściwości ozonu. Polska Akademia Nauk Oddział w Łodzi, Komisja Ochrony Środowiska, Łódź 2005.

[3] Rakness K.L.: OZONE in Drinking Water Treatment: Process Design, Operation, And Optimization. American Water Works Association, Denver 2005. 
[4] Huang WJ., Tsai YY., Chu Ch.: Evaluation of disinfection by-products formation during ozonation of bromide containing groundwater. Journal of Environmental Science and Health, Part A - Toxic/Hazardous Substances \& Environmental Engineering, vol. A38, no. 12, 2013, pp. 2919-2931.

[5] Zanacic E., Stavrinides J., Mc Martin D.W.: Field-analysis of potable water quality and ozone efficiency in ozone-assisted biological filtration systems for surface water treatment. Water Research, vol. 104, 2016, pp. 397-407.

[6] Muszański R.: Ogólne zasady projektowania instalacji oczyszczania wody, w których ozon jest zaawansowanym utleniaczem. [in:] Hydroprezentacje XVIII 2015. Ochrona wód, gospodarka wodna, zaopatrzenie w wodę i odprowadzanie ścieków, Krynica-Zdrój, 16-18 czerwca 2015 r. Sympozjum ogólnokrajowe, Śląska Rada Naczelnej Organizacji Technicznej. Federacja Stowarzyszeń Naukowo-Technicznych, Katowice 2015, pp. 93-107.

[7] Muszański R.: Ozonowanie wody - ogólne zasady projektowania instalacji oczyszczania wody $i$ ścieków z zastosowaniem ozonu. Zeszyt Specjalny Izby Gospodarczej "Wodociągi Polskie", Bydgoszcz 2015.

[8] Zimoch I., Natonek J.: Wykorzystanie ozonu w podnoszeniu bezpieczeństwa eksploatacji sieci wodociagowej. INSTAL, nr 5(384), 2017, pp. 34-38.

[9] “Ozon w Polsce" Conference, Krynica-Zdrój 2014 [WOFIL's internal materials].

\section{Wpływ czasu kontaktu fazy gazowej w wielostopniowych kolumnach kontaktowych ozonowania pośredniego na redukcję stężenia bromianów}

Streszczenie: W artykule zostały opisane badania nad zastosowaniem technologii ozonowania do oczyszczania wody powierzchniowej w obecności bromków. Instalacja pilotowa, na której przeprowadzono badania, wykorzystywała wielostopniowe kolumny kontaktowe do procesów ozonowania wody ze stabilizacją czasu kontaktu. Stwierdzono, że podstawą ograniczenia powstawania bromianów jest optymalna ilość ozonu resztkowego po procesach ozonowania oraz stały czas kontaktu z wodą. Dzięki temu rozwiązaniu można ograniczyć powstawanie związków szkodliwych dla zdrowia i zastosować technologię wykorzystującą ozon do wód zawierających prekursory związków kancerogennych.

Słowa

kluczowe: ozon, wielostopniowe kolumny kontaktowe, ozon resztkowy, stały czas kontaktu, bromiany 